\title{
Impacts of Changes in Consumption, Production and Trade Policies in China and India on the European Union and New Zealand
}

\author{
MEIKE GUENTHER \\ Lincoln University \\ Meike.Guenther@lincoln.ac.nz \\ CAROLINE SAUNDERS \\ Lincoln University \\ PETER TAIT \\ Lincoln University
}

\begin{abstract}
This study assessed the potential impacts of changes in meat and dairy consumption and production, as well as different trade policies in China and India, on agricultural trade in New Zealand (NZ) and the European Union (EU-27), using the Lincoln Trade and Environment Model (LTEM). This partial equilibrium model forecasts international trade, production and consumption of agricultural commodities. Several scenarios were developed simulating different ranges of consumption and production of meat and dairy commodities, as well as full trade liberalisation in China and India. Results showed that changing consumption, production and trade patterns in India and China could lead to higher producer returns from meat and dairy commodities in $\mathrm{NZ}$ and the EU-27 by 2020. However, if China and India significantly increase meat and dairy consumption and production simultaneously, producer returns in $\mathrm{NZ}$ and the EU-27 could decline.
\end{abstract}

Keywords: developing countries, New Zealand, European Union, meat and dairy consumption, trade liberalisation, partial equilibrium model,

\section{Introduction}

Worldwide, food consumption is growing and is mainly driven by a growing population, urbanisation and rising incomes in developing countries. In China and India, the growth in food consumption is accompanied by a shift in dietary patterns away from staples towards more livestock products, such as meat and dairy products and vegetable oils. ${ }^{1}$ These changes will have implications for domestic consumption, production and trade in New Zealand and the European Union (EU).

\footnotetext{
${ }^{1}$ Food and Agriculture Organization of the United Nations (FAO), The State of Food and Agriculture 2009, Rome, Italy: FAO, 2009; FAO, Global Trends and Future Challenges for the Work of the Organization, 69th Session of the Committee on Commodity Problems of the FAO, Rome, 28-30 May 2012.
} 
The aim of this study was to assess how different consumption and production patterns of meat and dairy commodities in China and India, as well as changing trade policies in both countries, may affect the agricultural sector and trade in the EU and New Zealand. Information gained from this study will assist policy makers in identifying new trade opportunities with emerging markets such as China and India.

New Zealand is a small open economy heavily dependent on its agricultural exports, particularly from the meat and dairy sector. Over the past decades, New Zealand's export focus has changed: whereas previously almost all exports went to Europe, more exports are now being directed into Asian markets, especially to China. The growth in trade flows between China and New Zealand has been facilitated by the Free Trade Agreement (FTA) between both countries that came into force in 2008. This provides for the removal of tariffs on $96 \%$ of traded goods over a 12-year-period, coming fully into force in 2019. ${ }^{2}$ Since 2010, China has been New Zealand's main export market for agricultural commodities. In 2014, New Zealand's agricultural exports to China were valued at NZ\$8.4 billion, a $64 \%$ increase from the previous year. 3 In contrast, New Zealand's agricultural exports to India have fluctuated since 2008, reaching a peak in 2010 with exports valued at $\$ 229$ million, mainly from dairy. The fluctuation in New Zealand exports to India are affected by restricted Indian trade policies. With current negotiations of a FTA between both countries, India has the potential to become an important export market for New Zealand.4

The European Union (EU) is the largest exporter of agricultural and food products. 5 In the last two decades, China in particular grew significantly in importance as a trading partner to the EU. Between 2010 and 2014, agricultural exports from the EU to China more than doubled, and in 2014 China was the EU's third largest export market in agricultural commodities, with exports worth 7.4 billion Euros. The largest export shares were recorded for 'beverages, spirits and vinegar' accounting for $18 \%$ of all agrifood exports to China in 2014, followed by 'meat and edible meat offal' accounting for $14 \%$ of total agri-food exports to China in the same year. ${ }^{6}$ The EU is committed to enhancing trade relationships further with China; in 2013 China and the EU have announced that they would commence negotiations of a comprehensive EU-China Investment Agreement aimed at providing liberalisation of investment as well as the elimination of restrictions for investors to each other's markets. 7 India is also an important trading partner to the EU. Between 2010 and 2014, agricultural exports from the EU to India almost doubled, with exports valued at 550 million Euros in 2014. In the same year, the largest export shares were recorded for 'beverages, spirits and vinegar' accounting for $30 \%$ of all agri-food exports to India, followed by 'animal or

\footnotetext{
${ }^{2}$ Ministry of Foreign Affairs and Trade (MFAT), New Zealand-China Free Trade Agreement, Wellington, NZ, MFAT: 2008.

3 Statistics New Zealand (SNZ), Global New Zealand - International Trade, Investment and Travel Profile: Year ended June 2014, Wellington, NZ: Statistics New Zealand, 2014.

4 MFAT, New Zealand-India Free Trade Agreement, Wellington, NZ, MFAT, 2013, accessed 15 October 2015, http://www.mfat.govt.nz/Trade-and-Economic-Relations/2-Trade-Relationships-and-Agreements/India/

5 European Commission (EC), Agri-Food Trade in 2014: EU-US Interaction Strengthened', Bruxelles: EC, 2015, accessed 15 October 2015, http://ec.europa.eu/agriculture/trade-analysis/map/2015-1_en.pdf

${ }^{6}$ EC, EU-28 Agri-Food Trade with China, Bruxelles: European Commission, 2015 accessed 15 October 2015, http://ec.europa.eu/agriculture/trade-analysis/statistics/outside-eu/2015/china_en.pdf

7 EC, Trade. Policy. China, Bruxelles: European Commission, 2015, accessed 15 October 2015,

http://ec.europa.eu/trade/policy/countries-and-regions/countries/china/
} 
vegetable fats and oils' accounting for $8 \%$ of total agri-food exports to India. ${ }^{8}$ In 2007 , the EU commenced negotiations towards a FTA with India. 9

This paper is structured as follows. The next section describes changing consumption, production and trade patterns in India and China. A literature review then assesses studies and their methods. This is followed by a description of the modelling approach of this study and scenario development. Then results will be described and discussed. The paper finishes with brief conclusions.

\section{Changes in Consumption, Production and Trade Patterns in India and China}

Traditionally, Indian and Chinese diets had a low intake of animal products and a large proportion of cereals, ${ }^{10}$ but dietary patterns are changing, in particular, there is an increase in consumption of livestock products. ${ }^{11}$ Urbanisation and rising incomes are generally considered to be the strongest drivers of increased consumption of livestock products in these countries. ${ }^{12}$ Several studies have found that urban residents typically consume more high value products, such as meat, and larger amounts of pre-cooked, fast and convenience foods than people in rural areas. ${ }^{13}$ This is due to relatively higher income elasticities of demand for meat and dairy products in cities compared to rural areas. ${ }^{14}$ The OECD FAO Agricultural Outlook ${ }^{15}$ has shown that the consumption of meat and dairy products is expected to continue to grow in China and India. However, it is not only the consumption of these products that has increased: milk and meat production have also more than doubled in both countries since $1990,{ }^{16}$ and are projected to continue to grow significantly by $2024 \cdot{ }^{17}$

\footnotetext{
${ }^{8}$ EC, EU-28 Agri-Food Trade with India, Bruxelles: EC, 2015, accessed 15 October 2015, http://ec.europa.eu/agriculture/trade-analysis/statistics/outside-eu/2015/india_en.pdf 9 EC, Trade. Policy. India, Bruxelles: EC, 2015.

${ }^{10}$ Vaclav Smil, Eating Meat: Evolution, Patterns, and Consequences, Population and Development Review, Vol. 28, No. 4, 2002: pp. 599-639, doi:10.1111/j.1728-4457.2002.00599.x.

${ }^{11}$ OECD FAO, OECD-FAO Agricultural Outlook 2012-2021, Paris, France: Organisation for Economic Cooperation and Development (OECD) Publishing, 2012, doi:10.1787/agr_outlook-2012-en; Fengxia Dong and Frank Fuller, Dietary Change in China's Cities: Empirical Fact or Urban Legend, Working Paper 06-WP 437, 2007, Center for Agricultural and Rural Development, Iowa State University, USA.

${ }^{12}$ Anita Regmi, 'Changing Structure of Global Food Consumption and Trade: An Introduction', in Changing Structure of Global Food Consumption and Trade. Agriculture and Trade Report WRSO1-1, ed. Anita Regmi, Washington D.C, USA: Market and Trade Economics Division, Economic Research Service, United States Department of Agriculture, 2001, pp. 1-3; V. Goel, Recent Shifts in Global Food Consumption Patterns and Future Scenarios, Proceedings of the 2oth Annual World Forum and Symposium on Navigating the Global Food System in a New Era of the International Food and Agribusiness Management Association (IFAMA), Washington, D.C., USA, 19 - 22 June 2010; Swarna Vepa, 'Impact of Globalization on the Food Consumption in Urban India,' in Globalization of Food Systems in Developing Countries: Impact on Food Security and Nutrition, ed. FAO, Rome, Italy: FAO Food and Nutrition Paper 83, 2004, pp. 215-230; FAO, 2009.

13 Josef Schmidhuber and Prakash Shetty, The Nutrition Transition to 2030. Why Developing Countries are Likely to Bear the Major Burden', Acta Agriculturae Scand Section C2, Vol. 3-4, 2005: pp. 150-166; Betty King, J.L. Tietyen, and S.S. Vickner, Consumer Trends and Opportunities, Lexington, USA: University of Kentucky, 2000; Allan Rae, The Effects of Expenditure Growth and Urbanization on Food Consumption in East Asia: A Note on Animal Products, Agricultural Economics, Vol. 18, No. 3, 1998: pp. 291-299, doi:http://dx.doi.org/10.1016/So169-5150(97)00051-0.

${ }_{14}$ Prabu Pingali and Yasmeen Khwaja, Globalisation of Indian Diets and the Transformation of Food Supply Systems, Inaugural Keynote Address of the 17th Annual Conference of the Indian Society of Agricultural Marketing, Hyderabad, India, 5-7 February 2004.

15 OECD FAO, OECD-FAO Agricultural Outlook 2015-2024, Paris, France: OECD Publishing, 2015.

${ }^{16}$ FAOSTAT, Food Balance Sheets. Commodity Balances, Rome, Italy: FAO, 2012,

17 OECD FAO, 2015.
} 
Since 1979, China's trade has expanded steadily, particularly after its accession to the WTO in 2001. Since then, China has opened up its borders by increasing its number of bilateral trade agreements and becoming a greater net importer of agricultural commodities. ${ }^{18}$ In 2008, New Zealand was the first OECD country to sign a FTA with China. Since then, China has signed further FTAs with Switzerland, Iceland, Chile and Singapore, among others, and is in negotiations with several other countries, such as Australia and Norway. ${ }^{19}$

India has a relatively small share in world trade, and its trade policies are very restricted, particularly for agricultural commodities. However, India is currently engaged in several international trade negotiations (e.g. Doha Round at the WTO), and there are negotiations towards bilateral FTAs with the EU, New Zealand and other South Asian countries, among others. The negotiations for a comprehensive FTA with the EU have been ongoing since June 2007. ${ }^{20}$ Similarly, negotiations towards a bilateral free trade agreement with New Zealand started in 2010, and in July 2013 New Zealand hosted the ninth round of the negotiations. ${ }^{21}$

\section{Modelling Changes in Consumption, Production and Trade Patterns}

Trade modelling approaches have been widely adopted in the modelling of global changes in consumption and production patterns and trade policies. There are two analytical frameworks: the partial equilibrium (PE) approach and the general equilibrium (GE) approach. While GE models examine supply and demand for all commodities simultaneously in all sectors and countries and consider the interactions with factor markets, ${ }^{22}$ PE models assume interactions within only one or a few industry sectors of the economy and ignore interactions with the rest of the economy, but usually have a higher level of commodity disaggregation. 23 Many studies have employed PE and GE models to analyse consumption and production growth in China and India and how they affect global food demand, supply and international trade. ${ }^{24}$

\footnotetext{
${ }_{18}$ Thomas Rumbaugh and Nicolas Blancher, China International Trade and WTO Accession, International Monetary Fund Working Paper WP/o4/36, Washington, D.C., USA: IMF, 2004.

${ }_{19}$ China FTA Network, China's Free Trade Agreements, 2012, accessed 11 October 2015, http://fta.mofcom.gov.cn/english/index.shtml

${ }^{20}$ Sandra Polaski, A. Ganesh-Kumar, Scott McDonald, Manoj Panda and Sherman Robinson, India's Trade Policy Choices. Managing Diverse Challenges, Institute for Development Studies and Indira Gandhi Institute of Development Research, Washington, D.C., USA: Carnegie Endowment for International Peace, 2008. ${ }^{21}$ MFAT, 2013.

${ }^{22}$ Roberta Piermartini and Robert Teh, Demystifying Modelling Methods for Trade Policy, World Trade Organization Discussion Papers No. 10, Geneva, Switzerland: WTO, 2005.

${ }^{23}$ Selim Cagatay and Caroline Saunders, Lincoln Trade and Environment Model: An Agricultural Multi-Country Multi-Commodity Partial Equilibrium Framework, Lincoln, New Zealand: Lincoln University, Agribusiness and Economics Research Unit, Research Report No. 254, 2003; Frank van Tongeren, Hans van Meijl and Yves Surry, Global Models Applied to Agricultural and Trade Policies: A Review and Assessment, Agricultural Economics, Vol. 26, No. 2, 2001: pp. 149-172. doi:10.1111/j.1574-0862.2001.tbooo6o.x; Vernon Roningen, 'Multi-Market, MultiRegion Partial Equilibrium Modeling', in Applied Methods for Trade Policy Analysis: A Handbook, ed. Joseph François and Kenneth Reinert, Cambridge, U.K.: Press Syndicate of the Cambridge University Press, 1997, pp. 231-257.

${ }_{24}$ Christopher Delgado, Mark Rosegrant, Henning Steinfeld, Simeon Ehui, and Claude Courbois, Livestock to 2020. The Next Food Revolution, Food, Agriculture, and the Environment Discussion Paper 28, Washington, D.C., USA: International Food Policy Research Institute/ Food and Agriculture Organization of the United Nations/ International Livestock Research Institute, 1999; Mark Rosegrant, Michael Paisner, Siet Meijer, and Julie Witcover, Global Food Projections to 2020. Emerging Trends and Alternative Futures, Washington, D.C.: International Food Policy Research Institute, 2001; Kym Anderson and Anna Strutt, Agriculture and Food Security in Asia by 2030, Working Paper 368, Tokyo, Japan: Asian Development Bank Institute (ADBI), 2012;
} 
Several empirical studies used PE models to project China and India's growth and changes in food consumption and production, as well as their impacts on other countries' consumption, production and trade patterns. In their study, Rosegrant et al. used the IMPACT model (International Model for Policy Analysis of Agricultural Commodities and Trade) - a global agricultural PE model - to analyse global livestock product consumption and production by 2020. For China, they projected a doubling in beef consumption between 1997 and 2020, with similar growth projected for beef production. For India, the projected increase in meat and milk consumption was greater than the projected growth in production. ${ }^{25}$ This was in line with Delgado et al, who showed that for India and China, the projected increase in meat and milk consumption was greater than the projected growth in production. ${ }^{26}$

A number of studies were conducted when China joined the WTO in 2001 focusing on impacts for China's food demand and supply and global trade patterns from these trade reforms. For example, Huang et al. examined the impacts of trade liberalisation on China's agricultural sector using the PE model CAPSiM (Chinese Agricultural Policy's Agricultural Policy Simulation and Projection Model). The model was particularly developed for the analysis of agricultural policies affecting the sector's production, consumption, commodity prices and trade in China. The study found that under full agricultural trade liberalisation, the aggregated price for food was projected to rise by $5 \%$, while crop prices were expected to decline by about 2 to $4 \% .27$

Saunders et al. examined the impacts of agricultural trade liberalisation of dairy products on New Zealand's agricultural sector. ${ }^{28}$ The study used the Lincoln Trade and Environment Model (LTEM), a PE model focusing on the agricultural sector. ${ }^{29}$ Results showed that New Zealand producer returns were projected to increase significantly from freer trade of dairy commodities. In contrast, EU producer returns were projected to drop in the case of fully liberalising dairy trade. $3^{\circ}$ Using the same model, Rasin examined the impacts of international full trade liberalisation and its effects on meat and dairy consumption, production and trade for several countries, particularly for New Zealand. Model results suggested that with full international trade liberalisation, New Zealand producer returns were predicted to increase from between $14 \%$ for beef to $37 \%$ for dairy commodities. Similarly, net trade from New Zealand was predicted to grow, with increased exports expected across all meat and dairy commodities. ${ }^{31}$

Many studies have used GE models to project future growth in food demand, supply and trade flows in China and other Asian countries, with the majority using the

\footnotetext{
Kym Anderson and Anna Strutt, The Changing Geography of World Trade: Projections to 2030, Journal of Asian Economics, Vol. 23, No. 4, 2012: pp. 303-323, doi:10.1016/j.asieco.2012.02.001

25 Rosegrant et al., 2001.

${ }^{26}$ Delgado et al., 1999.

${ }^{27}$ Jikun Huang, Yang Jun, Zhigang Xu, Scott Rozelle, and Ninghui Li, Agricultural Trade Liberalization and Poverty in China, China Economic Review, Vol. 18, 2007: pp. 244-265. doi: http://dx.doi.org/10.1016/j.chieco.2007.02.003

${ }^{28}$ Caroline Saunders, Anita Wreford, and Selim Cagatay, Trade Liberalization and Greenhouse Gas Emissions: The Case of Dairying in the EU and New Zealand, Australian Journal of Agricultural and Resource Economics, Vol. 50, No. 4, 2006: pp. 538-555, doi:10.1111/j.1467-8489.2006.00343.x.

${ }^{29}$ Selim Cagatay, Caroline Saunders, and Anita Wreford, Lincoln Trade and Environment Model (LTEM): Linking Trade and Environment, Research Report No. 263, Lincoln University, NZ: Agribusiness and Economics Research Unit, 2003.

30 Saunders et al., 2006.

${ }^{31}$ Shanika Rasin, The Impact of Trade Liberalisation Policies in China for the Dairy and Meat Sectors, Masters thesis, Lincoln University, 2006, accessed 30 September 2015, http://hdl.handle.net/10182/2312
} 
standard or a modified version of the GTAP (Global Trade Analysis Project) model. ${ }^{2}$ In a recent study, Anderson and Strutt used the standard GTAP model to examine how economic growth in China and India would alter agricultural markets in other countries/regions and international trade flows. Model results indicated that China's shares of global agricultural exports were projected to decrease while India's were projected to increase significantly by 2030.33 In a similar study, Anderson and Strutt examined changes in trade patterns for high-income countries of the 'North' (i.e., Europe, North America, Australia and New Zealand, and Japan) and developing countries of the 'South' in the course of continuing economic growth and structural changes in Asia. Results suggested that the share of South-South trade in global trade was expected to grow significantly by 2030 when there was slower economic growth in the North or trade liberalisation within Asia. 34

To summarise, several studies have tried to predict future consumption and production for India and China, as well as effects of changing trade policies using PE and GE models. Modelling results from these studies projected varying growth rates in consumption and production of meat and dairy commodities in India and China, but only a few studies exist that examined impacts on agricultural supply and demand from changing consumption and production patterns elsewhere in New Zealand.

\section{Method}

This study used the Lincoln Trade and Environment Model (LTEM) in order to assess the effects of increased meat and dairy consumption and production in China and India, as well as full trade liberalisation in China and India on consumption, production and trade in the EU-27 and New Zealand. The LTEM is a multi-country, multi-commodity PE framework based upon VORSIM. 35 It focuses on the agricultural sector and ignores relationships with the rest of the economy. It was specifically modified to focus on New Zealand, its main trading partners and its policies. The LTEM includes 21 countries or regions (including the rest of the world (ROW)) and 22 commodities. The model includes a disaggregation of agricultural commodities, especially for dairy, and offers flexibility and transparency in terms of adding variables, equations, policies and data. The LTEM uses synthetic estimated parameters. ${ }^{6}$

Data in the LTEM includes country-specific producer and consumer prices production and consumption, beginning and ending stocks, producer and consumer subsidies and taxes, tariffs and quotas. In addition, the LTEM contains population data and GDP figures. In order to determine the effects on supply and demand, productivity growth rates, GDP growth rates and population growth rates are included. The base year of the model is 2008 and it projects to 2020. Historical data is included back to 1986. In the

\footnotetext{
${ }^{22}$ Thomas Hertel, Global Trade Analysis: Modelling and Applications, New York, USA: Press Syndicate of Cambridge University Press, 1997; Allan Rae and Thomas Hertel, Future Development in Global Livestock and Grains Markets: The Impacts of Livestock Productivity Convergence in Asia-Pacific, The Australian Journal of Agricultural and Resource Economics, Vol. 44, No. 3, 2000: pp. 393-422, doi:10.1111/1467-8489.00117; Allejandro Nin, Thomas Hertel, Kenneth Foster, and Allan Rae, Productivity Growth, Catching Up and Uncertainty in China's Meat Trade, Agricultural Economics, Vol. 31, No. 1, 2004: pp. 1-16, doi:http://dx.doi.org/10.1016/j.agecon.2003.01.004

33 Anderson and Strutt, 2012.

34 Anderson and Strutt, 2011.

35 Roningen, 1997.

${ }^{36}$ Cagatay et al., 2003.
} 
model, elasticities determine the responsiveness of domestic supply and demand to changing prices, production and consumption patterns and policy measures.

\section{Scenario Development}

As stated earlier, in India and China, food consumption is growing and changing, moving away from staples towards more livestock products. Two sources are used in this study as they included the most relevant growth rates necessary for scenario development for this study. These were Rosegrant et al. 37 and the OECD FAO Agricultural Outlook (2013). $3^{8}$ Both studies provide growth rates for different levels of consumption and production of meat and dairy products for India and China. This was the basis of the development of two different dietary scenarios simulating different consumption and production patterns in India and China. Hence, these scenarios include mixed consumption and production predictions for China and India which reflects the uncertainty around growth and changes in food consumption and production in these countries shown by the literature. The main purpose of these two scenarios is to assess the effects of varying levels of consumption and production patterns in India and China on the EU (EU-27) and New Zealand.

Since its accession to the WTO in 2001, China has increased its trade as well as its FTAs with countries such as New Zealand, Switzerland, Iceland, Chile, and Singapore, among others, and it is in negotiations with several other countries. Similarly, India is engaged in trade negotiations towards bilateral FTAs with several countries/regions, such as the EU and New Zealand. The reduction of trade barriers in India and China may change patterns of production, consumption and trade in other countries which is particularly interesting for the EU and New Zealand. Two trade scenarios were developed which simulate full trade liberalisation in China and India in 2008, respectively. The main purpose of these scenarios is to evaluate the impact of full trade liberalisation in China and India on producer returns in New Zealand and the EU. While this situation is unlikely to occur in reality, it does provide some insights into the effects of India's and China's trade policies relative to the baseline scenario. The four scenarios are shown in Table 1.

\begin{tabular}{l|l}
\hline Scenario & Type \\
\hline BL & Baseline \\
1 & $\begin{array}{l}\text { Increase of meat and dairy consumption and production in India and } \\
\text { China (Rosegrant et al., 2001) }\end{array}$ \\
2 & $\begin{array}{l}\text { Change of meat and dairy consumption and production in India and } \\
\text { China (OECD FAO Agricultural Outlook, 2013) }\end{array}$ \\
3 & Full trade liberalisation in China \\
4 & Full trade liberalisation in India \\
\hline
\end{tabular}

Table 1: Modelling scenarios

The first scenario assumed an increase in meat and dairy consumption and production in India and China using growth rates from Rosegrant et al.39 These growth rates were annualised and applied to the period of 2008 and 2020. Overall, growth rates for

37 Rosegrant et al., 2001.

$3^{8}$ OECD FAO, 2013.

39 Rosegrant et al., 2001. 
consumption and production were very similar across meat and dairy commodities in both countries. While Indian meat and dairy consumption increased by more than $50 \%$ by 2020, Indian production growth rates were slightly smaller, at more than $40 \%$ for meat and dairy commodities. For China, growth rates for dairy consumption were predicted to be more than $60 \%$, beef consumption was expected to more than double and sheep meat consumption to increase by more than $40 \%$ by 2020 . China's production growth rates were similar to consumption growth for most commodities, at $60 \%$ for all dairy commodities, $100 \%$ for beef and $27 \%$ for sheep meat.

In Scenario 2, growth rates estimated by the OECD FAO Agricultural Outlook 40 were used which provided a more varied range of sub-commodities in contrast to those used in Scenario 1. Indian dairy consumption was predicted to increase significantly, with, for example, cheese consumption to increase fivefold by 2020. Indian meat consumption was predicted to increase by $30 \%$. In addition, growth rates for dairy production ranged from $83 \%$ for butter to $15 \%$ for whole milk powder (WMP) and were therefore significantly lower than for dairy consumption. For China, growth rates for meat consumption were predicted to be $20 \%$ while those for dairy consumption were predicted to be significantly higher, with, for example, skim milk powder consumption expected to more than double by 2020. In contrast, China's production growth rates for meat commodities were predicted to be below $20 \%$ and for dairy commodities they were below $40 \%$.

Finally, in Scenario 3, a complete removal of export subsidies, tariffs, and non-tariff barriers in China in 2008 is simulated, while in Scenario 4, the complete elimination of trade barriers in India in 2008 is simulated. Trade policies in all other countries in the model remain unchanged.

\section{Results and Discussion}

In this section, the results of the modelling of the four scenarios are presented. While the model produces a considerable amount of data for all countries, the presentation of results is limited to those directly relevant to the scope of this study. This is for New Zealand and the EU (EU-27), and for the commodities sheep meat, beef, cheese, butter, skim milk powder and whole milk powder. For these countries and commodities, producer returns are examined. Producer returns refer to the total return earned by the producers and are calculated by multiplying the quantity of a commodity produced in a country by its price. Impacts of each scenario are presented as expected percentage changes for producer returns from the baseline in 2020 for the EU and New Zealand.

The results from the two dietary scenarios showed the differences in outcomes between various growth rates of meat and dairy consumption and production changes in India and China. Overall, it was shown that increased meat and dairy consumption and production in India and China were predicted to have moderate effects on producer returns on both New Zealand and the EU by 2020.

40 OECD FAO, 2013. 


\begin{tabular}{c|cc}
\hline & New Zealand & EU-27 \\
\hline Beef & 1 & 1 \\
Sheep meat & 15 & 11 \\
Butter & -9 & -11 \\
Cheese & -2 & -1 \\
Whole Milk Powder & -9 & -13 \\
Skim Milk Powder & 1 & 1 \\
\hline
\end{tabular}

Table 2. Change to New Zealand (NZ) and European Union (EU-27) producer returns from high growth rates in meat and dairy production and consumption in India and China (Rosegrant) to 2020, in \% (changes base to scenario)

In Scenario 1, China and India increased meat and dairy consumption and production by relatively large growth rates evenly distributed across all meat and dairy commodities, yet the impacts on New Zealand and EU producer returns were varied. Table 2 shows that for New Zealand the largest increase was predicted for returns from sheep meat, increasing by $15 \%$ by 2020 . New Zealand producer returns from dairy commodities were predicted to fall, particularly from whole milk powder and butter which were predicted to drop by $9 \%$, each. Similarly, EU producer returns from sheep meat were predicted to increase by $11 \%$, while producer returns across all dairy commodities were predicted to fall by 2020, with the largest drops predicted for whole milk powder, falling by $13 \%$. These drops are due to declines in producer prices for dairy commodities and the subsequent drop in dairy production.

\begin{tabular}{c|cc}
\hline & New Zealand & EU-27 \\
\hline Beef & 1 & 1 \\
Sheep meat & 9 & 6 \\
Butter & -11 & -19 \\
Cheese & 1 & 0 \\
Whole Milk Powder & 6 & 10 \\
Skim Milk Powder & 10 & 7 \\
\hline
\end{tabular}

Table 3. Change to New Zealand (NZ) and European Union (EU-27) producer returns from mixed growth rates in meat and dairy production and consumption in India and China (OECD FAO Agricultural Outlook, 2013) to 2020, in \% (changes base to scenario)

In Scenario 2, China and India's growth rates for meat and dairy consumption and production were based on the OECD FAO Agricultural Outlook (2013) projections which were more varied than in Scenario 1. Table 3 shows that New Zealand producer returns for these commodities were predicted to increase by 2020 (except for butter) compared to the base, as a consequence of higher prices and production growth. The largest increase was predicted for returns from skim milk powder $(+10 \%)$, then sheep meat $(+9 \%)$. New Zealand producer returns from butter were predicted to decline (11\%). Results for the EU showed the largest increase in producer returns from whole milk powder which were predicted to increase by $10 \%$ by 2020 . This in contrast to Scenario 1, where EU producer returns for whole milk powder were predicted to drop as a consequence of higher producer prices and subsequent production growth. 
Further, EU returns from butter were predicted to drop by $19 \%$ by 2020. This significant drop is due to declines in butter prices and drops in butter production.

\begin{tabular}{c|cc}
\hline & New Zealand & EU-27 \\
\hline Beef & 3 & 3 \\
Sheep meat & 8 & 6 \\
Butter & 3 & 1 \\
Cheese & 3 & 1 \\
Whole Milk Powder & 7 & 10 \\
Skim Milk Powder & 2 & 1 \\
\hline
\end{tabular}

Table 4. Change to New Zealand (NZ) and European Union (EU-27) producer returns from full trade liberalisation in China to 2020 , in $\%$ (changes base to scenario)

Scenario 3 assumed a complete removal of China's export subsidies, tariffs, production quota, and intervention prices in 2008, while trade policies in all other countries in the model remained unchanged. Results presented in Table 4 show that for New Zealand, China's full trade liberalisation results in increases in producer returns across all meat and dairy commodities with the greatest increase expected for returns from sheep meat $(+8 \%)$, then whole milk powder $(+7 \%)$. This is a consequence of production growth following higher producer prices across all meat and dairy commodities. China's full trade liberalisation has similar impacts on the EU. Producer returns were predicted to increase across all meat and dairy commodities by 2020 with the greatest increase predicted for whole milk powder $(+10 \%)$, then sheep meat $(+6 \%)$. This is also a consequence of higher producer prices and growth in production. However, in comparison, fully liberalising trade in China was expected to have larger effects on New Zealand producer returns than on EU producer returns, except for whole milk powder.

\begin{tabular}{c|cc}
\hline & New Zealand & EU-27 \\
\hline Beef & 2 & 2 \\
Sheep meat & 4 & 3 \\
Butter & 7 & 8 \\
Cheese & 2 & 0.02 \\
Whole Milk Powder & 2 & 0.40 \\
Skim Milk Powder & 7 & 5 \\
\hline
\end{tabular}

Table 5. Change to New Zealand (NZ) and European Union (EU-27) producer returns from full trade liberalisation in India to 2020 , in $\%$ (changes base to scenario)

Scenario 4 assumed a complete removal of India's export subsidies, tariffs, production quota, and intervention prices in 2008, while trade policies in all other countries in the model remained unchanged. As shown in Table 5, for New Zealand, India's full trade liberalisation would lead to increased producer returns for all meat and dairy commodities by 2020 as a consequence of production growth relative to increased prices for these commodities. The highest increases were predicted for returns from butter and skim milk powder, projected to increase by $7 \%$ each by 2020 . In comparison, predicted increases in New Zealand producer returns were generally 
higher than producer returns for the EU, except for butter. The greatest increase in EU producer returns was predicted for butter which was projected to increase by $8 \%$ by 2020 , followed by skim milk powder $(+5 \%)$. The growth in EU producer returns is also a consequence of higher producer prices for meat and dairy commodities and subsequent growth in production. However, comparing the effects on producer returns from fully liberalising trade in India in 2008, it was shown that the increases in New Zealand producer returns were higher (except for skim milk powder) than producer returns in the EU.

\section{Conclusion}

This study estimated and discussed possible changes in producer returns in the meat and dairy sector in New Zealand and the EU from changing consumption, production and trade patterns of meat and dairy commodities in India and China using the Lincoln Trade and Environment Model (LTEM). This partial equilibrium trade model simulates international trade as well as production and consumption of agricultural commodities.

Overall, this study showed that changing consumption and production patterns in India and China may lead to higher producer returns from meat and dairy commodities in the EU and New Zealand as a consequence of increased world prices and domestic production. For New Zealand, this would be particularly true if China and India develop as predicted by the OECD FAO Agricultural Outlook (2013), except for butter. However, when India and China significantly increased meat and dairy consumption and production simultaneously, New Zealand and EU producer returns, particularly from dairy, could decrease by 2020 due to drops in production relative to international prices. Under China's and India's full trade liberalisation, New Zealand and the EU would experience slight increases in producer returns across all meat and dairy commodities by 2020 as a consequence of production growth following higher producer prices.

To conclude, in China and India dietary patterns are changing away from cereals, tubers and pulses towards meat and dairy products, subsequently converging towards western diets. While this development could lead to higher producer returns for meat and dairy commodities in the EU and New Zealand, in some cases, drops in returns for dairy commodities might occur. This would be particularly true if China and India were able to meet domestic demand themselves. In contrast, full trade liberalisation in China and India would lead to higher producer returns in the EU and New Zealand across all meat and dairy commodities.

Future research in this area will include an update of the model's dataset, as well as parameter estimates, such as elasticities and growth rates, in order to focus on more recent years for the baseline projections. This will provide a more realistic picture of developments in the meat and dairy sector, especially in China, as well as on the effects of the free trade agreement between China and New Zealand.

\section{Acknowledgements}

The authors would like to thank the Agribusiness and Economics Research Unit (AERU) at Lincoln University in New Zealand for funding this project. 